\title{
Optical People Counting for Demand Controlled Ventilation: A Pilot Study of Counter Performance
}

\author{
William Fisk and Douglas Sullivan \\ Environmental Energy Technologies Division \\ Indoor Environment Department \\ Lawrence Berkeley national Laboratory \\ Berkeley, CA 94720
}

December 26, 2009

The research reported here was supported by the California Energy Commission Public Interest Energy Research program award number 600303000 and the Assistant Secretary for Energy Efficiency and Renewable Energy, Office of the Building Technologies Program, U.S. Department of Energy under Contract No. DE-AC02-05CH11231. 


\title{
Optical People Counting for Demand Controlled Ventilation: A Pilot Study of Counter Performance \\ Report to the California Energy Commission \\ Public Interest Energy Research Program
}

December 26, 2009

\author{
AUTHORS \\ William Fisk and Douglas Sullivan \\ Indoor Environment Department \\ Lawrence Berkeley national Laboratory \\ Berkeley, CA 94720 \\ Commission Project Manager: Brad Meister
}

Agreement No. 600303000

PIER Subject Area: Buildings End Use Energy Efficiency Program 


\section{DISCLAIMER}

This report was prepared as the result of work sponsored by the California Energy Commission. It does not necessarily represent the views of the Energy Commission, its employees or the State of California. The Energy Commission, the State of California, its employees, contractors and subcontractors make no warrant, express or implied, and assume no legal liability for the information in this report; nor does any party represent that the uses of this information will not infringe upon privately owned rights. This report has not been approved or disapproved by the California Energy Commission nor has the California Energy Commission passed upon the accuracy or adequacy of the information in this report.

\section{FINANCIAL SUPPORT}

The research reported here was supported by the California Energy Commission Public Interest Energy Research program award number 600303000 and the Assistant Secretary for Energy Efficiency and Renewable Energy, Office of the Building Technologies Program, U.S. Department of Energy under Contract No. DE-AC02-05CH11231. 


\section{ABSTRACT}

This pilot scale study evaluated the counting accuracy of two people counting systems that could be used in demand controlled ventilation systems to provide control signals for modulating outdoor air ventilation rates. The evaluations included controlled challenges of the people counting systems using pre-planned movements of occupants through doorways and evaluations of counting accuracies when naïve occupants (i.e., occupants unaware of the counting systems) passed through the entrance doors of the building or room. The two people counting systems had high counting accuracy accuracies, with errors typically less than $10 \%$, for typical nondemanding counting events. However, counting errors were high in some highly challenging situations, such as multiple people passing simultaneously through a door. Counting errors, for at least one system, can be very high if people stand in the field of view of the sensor. Both counting system have limitations and would need to be used only at appropriate sites and where the demanding situations that led to counting errors were rare.

\section{INTRODUCTION}

Standards for minimum outdoor air ventilation rates in most types of buildings typically prescribe minimum ventilation rates per occupant. Some standards also include minimum ventilation rates per unit floor area. The minimum ventilation rate per occupant is intended to limit indoor concentrations of bioeffluents and other pollutants emitted at a rate that varies with occupancy. The minimum ventilation rate per floor area is designed to maintain acceptable indoor concentrations of pollutants emitted from other sources, such as building materials and furnishings. Because occupancy is variable, the total prescribed minimum ventilation rate varies over time. In traditional demand controlled ventilation systems, minimum outdoor air ventilation rates are modulated over time based on measured indoor concentrations of carbon dioxide $\left(\mathrm{CO}_{2}\right)$ which are proxies for the indoor concentrations of pollutants generated by occupants and their activities and also proxies for ventilation rates per occupant. The goal is to keep outdoor air ventilation rates at or above design or code requirements but to also adjust the ventilation rates with changes in occupancy in order to save energy by avoiding over-ventilation relative to requirements (Fisk and de Almeida 1998; Brandemuehl and Braun 1999; Emmerich and Persily 2001). An alternative to using $\mathrm{CO}_{2}$ sensors is to count the number of people who enter and exit a building or section of a building and use the net count of people in the building or building section as an input to the ventilation rate control system. This document discusses pilot-scale evaluations of the accuracy of two people counting systems potentially usable for this application. This evaluation of people counting systems is motivated, in part, because the $\mathrm{CO}_{2}$ sensors typically used for demand controlled ventilation frequently have large measurement errors (Fisk et al. 2009). In theory, discrete counting of events, such as detection of the movement of persons through a space, may be less subject to errors, e.g., sensor performance degradation over time, than $\mathrm{CO}_{2}$ concentration measurements.

There are advantages and disadvantages of using people counting systems, relative to use of $\mathrm{CO}_{2}$ sensors, for demand controlled ventilation. Advantages include fast time response - people counters respond immediately while $\mathrm{CO}_{2}$ concentrations adjust over periods of minutes to hours 
after changes in occupancy. However, the delay in detecting occupancy with $\mathrm{CO}_{2}$ sensors is sometimes considered desirable as $\mathrm{CO}_{2}$-based demand controlled ventilation systems respond to a proxy for the indoor concentration of occupant-generated pollutants which is what the demand controlled ventilation is designed to control. If desired, software can be used to add a lag in the response times of demand controlled ventilation systems to counts of people. Another advantage of people counting is that its performance is not subject to errors caused by the exhaled breath of people. The high $\mathrm{CO}_{2}$ levels in exhaled breath of people located near a $\mathrm{CO}_{2}$ sensor can cause the sensor to respond to a localized elevated $\mathrm{CO}_{2}$ concentration as opposed to a room average $\mathrm{CO}_{2}$ concentration. A disadvantage of people counting is that it must be accompanied by a system for measuring the flow rate of outdoor air provided by the building's heating, ventilating, and air conditioning (HVAC) system. Accurate measurement of outdoor air flow rates is often very challenging (Fisk et al. 2006). $\mathrm{CO}_{2}$ sensors are often used for demand controlled ventilation without having any measurement system for the outdoor air flow rate, although, in such applications, the HVAC system may be unable to accurately provide the minimum outdoor air supply per unit floor area specified in the applicable ventilation standard. Another disadvantage of people counting for demand controlled ventilation is that a larger number of people counters than $\mathrm{CO}_{2}$ sensors may be necessary in small to moderate size meeting rooms with multiple doors. A people counter is required at each door while only a single $\mathrm{CO}_{2}$ sensor may be needed. Finally, for accuracy, people counters require a small zone near the door in which occupants do not sit or stand, while $\mathrm{CO}_{2}$ sensors are not subject to this restriction.

Optical people counting for demand controlled ventilation is a new technology. One of the products evaluated in this project was designed primarily for other applications, such as counting people entering a retail store for market-related purposes. The other technology evaluated is a prototype that is not yet available commercially. Consequently, this technology is likely to evolve and improve and its costs may decrease if production rates increase.

\section{METHODS}

People Counting System Number 1 (PCS1) uses thermal sensors (called cameras in installation literature), other electronics, and software to detect the movements of a warm human body in a field of view. Multiple sensors can be interconnected into an integrated counting system. The count of people passing through the field of view in both directions (i.e., in-count and out-count) is communicated to a connected computer system. In addition, low resolution thermal images of the moving people, insufficient for identification of individuals, can be viewed. Versions of sensors with different fields of view, represented by view angles of $20^{\circ}, 40^{\circ}$, and $60^{\circ}$ are available, with the wider view versions designed for installation closer to the floor. Per the manufacturer's literature and discussions with the manufacturer, PCS1 is best suited for applications in which the sensors can be installed at a height of $3.5 \mathrm{~m}(11.5 \mathrm{ft})$ for a sensor with a $60^{\circ}$ view, which is the version of sensor chosen for testing. The minimum recommend height for

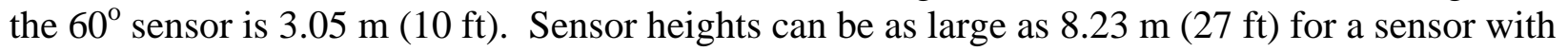
a 20 degree view. Individual sensors can detect passage of people through $0.91 \mathrm{~m}$ to $3.05 \mathrm{~m} \mathrm{(3 \textrm {ft }}$ to $10 \mathrm{ft}$ ) wide entrances. The sensor is to be installed indoors. The cost paid for the hardware used at a single door entrance was $\$ 1450$ and the cost of the hardware for the multi-door entrance was $\$ 3400$. 
People Counting System Number 2 (PCS2) uses sensors, other electronics, and software to detect the movements of people through a doorway. A detailed description of the principles of operation of the system was not available. Multiple people counters can be interconnected into an integrated counting system. The count of people in the room increases when a person enters and decreases when a person exits and is communicated to a connected computer system via the BACnet communication protocol. Each counter has two closely spaced sensors. Normally, the counter increases or decreases the total count by full person-units; however, in some situations the total count may increase or decrease by a half person (presumably when only one sensor detects movement). Using software, settings can be modified to optimize counting for different applications. For example, one setting affects how long the person needs to be detected and another affects the size of the person required before the count is incremented. These can be adjusted from baseline settings if people are expected to move very rapidly through a doorway or if children, as opposed to larger adults, are to be counted. Other settings enable or disable halfcounts or disallow or enable the sensor's accumulated count to become negative. Per the manufacturer's literature, the sensors for PCS2 are only for use on interior doors 0.81 to $0.91 \mathrm{~m}$ (32 to 36 inch) wide with a normal, e.g., $2.0 \mathrm{~m}$ (80 inch) height. The counter is installed above the center of the door, on the side of the door opposite the zone of the door swing. The height of the installed counter should be 2.13 to $2.44 \mathrm{~m}$ (84 to 96 inch). The evaluated version of PCS2 was a prototype undergoing beta testing. As a commercial product is not yet available, not product cost was available.

PCS1 was evaluated when installed at a single-door entrance to a laboratory, at the two-door entrance to a conference room, and at a four-door-wide entrance to an office building. The total entrance width of the system of four doors was $4.8 \mathrm{~m}(15.8 \mathrm{ft})$. A single thermal sensor was employed at the interior door entrances and two interconnected thermal sensors were employed at the four door building entrance. The height of the installed sensors was as follows: 3.05, 3.10, 3.35, and $3.58 \mathrm{~m}$ ( $10,10.2,11$, and $11.7 \mathrm{ft})$ at the single-door entrance to the laboratory, $3.5 \mathrm{~m}$ $(11.5 \mathrm{ft})$ at the two-door entrance to a conference room, and $3.12 \mathrm{~m}(10.25 \mathrm{ft}) \mathrm{m}$ at the four-door entrance to the office building. The software allows the user to change the location of some lines in the field of view that must be crossed by the moving thermal image of a person to create an incount or out-count. The positions of lines were adjusted to maximize counting accuracy as people moved through the entrance during initial system checkouts. For example, at the twodoor entrance to the conference room most occupants turned left immediately after entering the room and the lines were adjusted to improve counting of people passing through a zone to the left of the doors.

PCS2 was evaluated when installed in accordance with the manufacturers' installation guidance at a single-door entrance of three rooms. Because the system was not intended for use at building entrance doors, no such tests were performed. The door widths were $0.91 \mathrm{~m}$ (36 inch) in all cases. Door heights were 2.10 to $2.16 \mathrm{~m}$ (83 to 85 inch) and the base of the sensor was approximately $5 \mathrm{~cm}$ ( 2 inch) above the top of the door. Only a single counter, not an integrated system of counters, was evaluated.

The evaluations assessed the accuracy of people counting used visual observations of people movement and record keeping to provide the reference counts. The evaluations included 
controlled challenges of the people counting systems using pre-planned movements of occupants through doorways and, in addition, evaluations of counting accuracy when naïve occupants (i.e., occupants unaware of the counting system) passed through the entrance doors of the building or room. The controlled challenges are identified in Table 1. Some of the controlled challenges were highly demanding and may infrequently be encountered in practice. There were a few time periods when the person evaluating the systems were uncertain of actual people counts and data from these time periods were not utilized.

In the first controlled evaluation of PCS2 at the entrance door to Conference Room 1 and during its use in Conference Room 1 to count naive occupant movement through the door, the "start threshold" was set at 100, which was the preprogrammed setting when the unit arrived from the manufacturer. After discussing the initial test results with the manufacturer, the "start threshold" was set to 300 which is the normal default setting per the manufacturer. Thus, the controlled tests in Room 3 and the evaluations of counting of naive occupant passage through the door of Conference Room 2 were performed with the "start threshold" set at 300. This threshold affects the size of person required to trigger the counter with the setting of 100 better enabling the system to detect children and the setting of 300 normally used to detect adults. Other settings (e.g., event $=300$, cross $=50$ ) remained throughout the study with the default values preprogrammed in PCS2.

\section{RESULTS}

\section{People Counting System Number 1.}

Table 1 provides a compilation of results of counting accuracy with controlled challenges of PCS1 at the single-door entrance to a laboratory. There were no counting errors when single persons walked through the door at a normal or very fast pace except when carrying an open or covered coffee cup containing hot water heated within the last few minutes to the boiling point or wearing a room temperature heavy winter coat with hood covering the head and with the person's hands in the coat pockets. Carrying a cup of hot water resulted in frequent over counting (i.e., the measured count was two when the correct count was one) while carrying a warm laptop computer held flat to the floor resulted in no errors. Wearing the room temperature winter coat resulted in frequent under counting, i.e., some of those who passed through the door were not counted. There were no counting errors when two persons walked through the door side-by-side but not touching each other; however, if one person had their arm over the shoulder of the other person the system sometimes produced an undercount. When two people walked through the door with the second closely following the first, there were no counting errors, but with three or five persons walking through the door in very close succession, there were some counting errors.

Table 2 provides the results of a very similar set of tests with controlled challenges of PCS1 at the four-door entrance to an office building. The results are qualitatively similar to those of the tests from the single-door entrance of the laboratory except there was some undercounting when single persons exited through the door system at a normal or very fast pace. 
Table 1. Results of controlled tests of PCS1 at a single interior door entrance to a laboratory, the numbers are averages of three repeated challenges.

\begin{tabular}{|c|c|c|c|c|c|c|c|}
\hline \multirow{2}{*}{ Test Conditions } & \multirow{2}{*}{$\begin{array}{c}\text { Sensor } \\
\text { Height } \\
\text { (m) }\end{array}$} & \multirow{2}{*}{$\begin{array}{l}\text { Cor- } \\
\text { rect } \\
\text { Count }\end{array}$} & \multicolumn{2}{|c|}{$\begin{array}{l}\text { Entrances } \\
\text { Through Door }\end{array}$} & \multicolumn{2}{|c|}{$\begin{array}{l}\text { Exits Through } \\
\text { Door }\end{array}$} & \multirow{2}{*}{$\begin{array}{c}\text { Entran } \\
\text {-ces or } \\
\text { Exits } \\
\text { Count- } \\
\text { ing } \\
\text { Error } \\
(\%)\end{array}$} \\
\hline & & & $\begin{array}{l}\text { Avg. } \\
\text { Count }\end{array}$ & $\begin{array}{c}\text { Count } \\
\text { - ing } \\
\text { Error } \\
(\%)\end{array}$ & $\begin{array}{l}\text { Avg. } \\
\text { Count }\end{array}$ & $\begin{array}{c}\text { Count } \\
\text {-ing } \\
\text { Error } \\
(\%)\end{array}$ & \\
\hline $\begin{array}{l}\text { single person walks through at a } \\
\text { normal pace }\end{array}$ & $\begin{array}{l}3.05 \\
3.10 \\
3.35 \\
3.58 \\
\end{array}$ & $\begin{array}{l}1 \\
1 \\
1 \\
1 \\
\end{array}$ & $\begin{array}{l}1 \\
1 \\
1 \\
1 \\
\end{array}$ & $\begin{array}{l}0 \\
0 \\
0 \\
0 \\
\end{array}$ & $\begin{array}{l}1 \\
1 \\
1 \\
1\end{array}$ & $\begin{array}{l}0 \\
0 \\
0 \\
0 \\
\end{array}$ & $\begin{array}{l}0 \\
0 \\
0 \\
0 \\
\end{array}$ \\
\hline $\begin{array}{l}\text { single person walks through at a } \\
\text { very fast pace }\end{array}$ & $\begin{array}{l}3.00 \\
3.05 \\
3.10 \\
3.35 \\
3.58 \\
\end{array}$ & $\begin{array}{l}1 \\
1 \\
1 \\
1 \\
1 \\
\end{array}$ & $\begin{array}{l}1 \\
1 \\
1 \\
1 \\
\end{array}$ & $\begin{array}{l}0 \\
0 \\
0 \\
0 \\
\end{array}$ & $\begin{array}{l}1 \\
1 \\
1 \\
1 \\
\end{array}$ & $\begin{array}{l}0 \\
0 \\
0 \\
0 \\
\end{array}$ & $\begin{array}{l}0 \\
0 \\
0 \\
0 \\
\end{array}$ \\
\hline $\begin{array}{l}\text { single person walks through at a } \\
\text { normal pace with covered coffee } \\
\text { cup }\end{array}$ & $\begin{array}{l}3.05 \\
3.10 \\
3.35 \\
3.58\end{array}$ & $\begin{array}{l}1 \\
1 \\
1 \\
1\end{array}$ & $\begin{array}{c}1.67 \\
2 \\
1.67 \\
1.67\end{array}$ & $\begin{array}{c}67 \\
100 \\
67 \\
67 \\
\end{array}$ & $\begin{array}{c}1 \\
1.67 \\
1.33 \\
1 \\
1\end{array}$ & $\begin{array}{c}67 \\
33 \\
0 \\
0\end{array}$ & $\begin{array}{l}67 \\
67 \\
33 \\
33\end{array}$ \\
\hline $\begin{array}{l}\text { single person walks through at a } \\
\text { normal pace with open coffee } \\
\text { cup }\end{array}$ & $\begin{array}{l}3.05 \\
3.10 \\
3.35 \\
3.58\end{array}$ & $\begin{array}{l}1 \\
1 \\
1 \\
1\end{array}$ & $\begin{array}{c}1.67 \\
2 \\
1.67 \\
1\end{array}$ & $\begin{array}{c}67 \\
100 \\
67 \\
0\end{array}$ & $\begin{array}{c}2 \\
1.67 \\
1 \\
1\end{array}$ & $\begin{array}{c}100 \\
67 \\
0 \\
0\end{array}$ & $\begin{array}{c}83 \\
83 \\
33 \\
0\end{array}$ \\
\hline $\begin{array}{l}\text { single person walks through at a } \\
\text { normal pace with a room } \\
\text { temperature winter coat with } \\
\text { hood on and hands in pockets }\end{array}$ & $\begin{array}{l}3.05 \\
3.10 \\
3.35 \\
3.58\end{array}$ & $\begin{array}{l}1 \\
1 \\
1 \\
1\end{array}$ & $\begin{array}{l}1 \\
1 \\
0.67 \\
0.33\end{array}$ & $\begin{array}{c}0 \\
0 \\
-33 \\
-67\end{array}$ & $\begin{array}{c}0.67 \\
1 \\
0.33 \\
0\end{array}$ & $\begin{array}{c}-33 \\
0 \\
-67 \\
-100\end{array}$ & $\begin{array}{c}-16 \\
0 \\
-50 \\
-83\end{array}$ \\
\hline $\begin{array}{l}\text { single person walks through at a } \\
\text { normal pace, with a winter coat } \\
\text { from the freezer, with hood on } \\
\text { and hands in pockets }\end{array}$ & $\begin{array}{l}3.05 \\
3.10 \\
3.35 \\
3.58 \\
\end{array}$ & $\begin{array}{l}1 \\
1 \\
1 \\
1\end{array}$ & $\begin{array}{l}1 \\
1 \\
1 \\
1 \\
\end{array}$ & $\begin{array}{l}0 \\
0 \\
0 \\
0 \\
\end{array}$ & $\begin{array}{l}1 \\
1 \\
1 \\
1 \\
\end{array}$ & $\begin{array}{l}0 \\
0 \\
0 \\
0 \\
\end{array}$ & $\begin{array}{l}0 \\
0 \\
0 \\
0 \\
\end{array}$ \\
\hline $\begin{array}{l}\text { single person walks through at a } \\
\text { normal pace, with a warm laptop } \\
\text { computer held flat to the ground }\end{array}$ & $\begin{array}{l}3.05 \\
3.10 \\
3.35 \\
3.58 \\
\end{array}$ & $\begin{array}{l}1 \\
1 \\
1 \\
1\end{array}$ & $\begin{array}{l}1 \\
1 \\
1 \\
1\end{array}$ & $\begin{array}{l}0 \\
0 \\
0 \\
0 \\
\end{array}$ & $\begin{array}{l}1 \\
1 \\
1 \\
1\end{array}$ & $\begin{array}{l}0 \\
0 \\
0 \\
0 \\
\end{array}$ & $\begin{array}{l}0 \\
0 \\
0 \\
0 \\
\end{array}$ \\
\hline $\begin{array}{l}\text { two people walk through at a } \\
\text { normal pace, side by side, not } \\
\text { touching }\end{array}$ & $\begin{array}{l}3.05 \\
3.10 \\
3.35 \\
3.58 \\
\end{array}$ & $\begin{array}{l}2 \\
2 \\
2 \\
2\end{array}$ & $\begin{array}{l}2 \\
2 \\
2 \\
2\end{array}$ & $\begin{array}{l}0 \\
0 \\
0 \\
0\end{array}$ & $\begin{array}{l}2 \\
2 \\
2 \\
2\end{array}$ & $\begin{array}{l}0 \\
0 \\
0 \\
0\end{array}$ & $\begin{array}{l}0 \\
0 \\
0 \\
0\end{array}$ \\
\hline $\begin{array}{l}\text { two people walk through at a } \\
\text { normal pace, side by side, arm } \\
\text { over shoulder }\end{array}$ & $\begin{array}{l}3.05 \\
3.10 \\
3.35 \\
3.58\end{array}$ & $\begin{array}{l}2 \\
2 \\
2 \\
2\end{array}$ & $\begin{array}{l}2 \\
1.67 \\
1.67 \\
1.67\end{array}$ & $\begin{array}{c}0 \\
-17 \\
-17 \\
-17\end{array}$ & $\begin{array}{c}2 \\
2 \\
2 \\
1.67\end{array}$ & $\begin{array}{c}0 \\
0 \\
0 \\
-17\end{array}$ & $\begin{array}{l}0 \\
-8 \\
-8 \\
-17\end{array}$ \\
\hline $\begin{array}{l}\text { two people walk through at a } \\
\text { normal pace, second person } \\
\text { follows first as close as } \\
\text { comfortable }\end{array}$ & $\begin{array}{l}3.05 \\
3.10 \\
3.35 \\
3.58 \\
\end{array}$ & $\begin{array}{l}2 \\
2 \\
2 \\
2\end{array}$ & $\begin{array}{l}2 \\
2 \\
2 \\
2 \\
\end{array}$ & $\begin{array}{l}0 \\
0 \\
0 \\
0\end{array}$ & $\begin{array}{l}2 \\
2 \\
2 \\
2\end{array}$ & $\begin{array}{l}0 \\
0 \\
0 \\
0\end{array}$ & $\begin{array}{l}0 \\
0 \\
0 \\
0\end{array}$ \\
\hline $\begin{array}{l}\text { three people walk through at a } \\
\text { normal pace, one after another as } \\
\text { close as comfortable }\end{array}$ & $\begin{array}{l}3.05 \\
3.10 \\
3.35 \\
3.58\end{array}$ & $\begin{array}{l}3 \\
3 \\
3 \\
3\end{array}$ & $\begin{array}{c}3.33 \\
3 \\
3 \\
3\end{array}$ & $\begin{array}{l}11 \\
0 \\
0 \\
0\end{array}$ & $\begin{array}{c}3 \\
3 \\
3 \\
2.67\end{array}$ & $\begin{array}{c}0 \\
0 \\
0 \\
-11\end{array}$ & $\begin{array}{c}6 \\
0 \\
0 \\
-6\end{array}$ \\
\hline $\begin{array}{l}\text { five people walk through at a } \\
\text { normal pace, one after another as } \\
\text { close as comfortable }\end{array}$ & $\begin{array}{l}3.05 \\
3.10 \\
3.35 \\
3.58\end{array}$ & $\begin{array}{l}5 \\
5 \\
5 \\
5\end{array}$ & $\begin{array}{l}5 \\
4.33 \\
4.33 \\
5\end{array}$ & $\begin{array}{c}0 \\
-13 \\
-13 \\
0\end{array}$ & $\begin{array}{l}4.33 \\
5 \\
4.33 \\
3.67\end{array}$ & $\begin{array}{c}-13 \\
0 \\
-13 \\
-26\end{array}$ & $\begin{array}{l}-7 \\
-7 \\
-13 \\
-13\end{array}$ \\
\hline
\end{tabular}


Table 2. Results of controlled tests of PCS1 system at a four-door entrance of an office building*.

\section{Test Conditions}

single person walks through at a

normal pace

single person walks through at a very

fast pace

single person walks through at a

normal pace with covered coffee cup.

(lid temperature $143^{\circ} \mathrm{F}$ )

single person walks through at a

normal pace with open coffee cup.

(coffee temperature $173^{\circ} \mathrm{F}$ )

single person walks through at a

normal pace with a room temperature

winter coat with hood on and hands in

pockets, hands briefly out to open door

single person walks through at a

normal pace, with a winter coat from

the freezer, with hood on and hands in

pockets, hands briefly out to open door

(coat surface temperature $36{ }^{\circ} \mathrm{F}$ )

single person walks through at a

normal pace, with a warm laptop held

flat to the ground ( laptop surface

temperature $86{ }^{\circ} \mathrm{F}$ )

two people walk through at a normal

pace, side by side, not touching

two people walk through at a normal

pace, side by side, arm over shoulder

two people walk through at a normal

pace, second person follows first as

close as comfortable

three people walk through at a normal

pace, one after another as close as

comfortable

five people walk through at a normal

pace, one after another as close as

comfortable

\section{Entrances \\ Through Door}

$\begin{array}{ll}\text { Num } & \text { Counting } \\ \text {-ber } & \text { Error (\%) }\end{array}$

12

12

12

12

12

12

12

24

24

24

36

60

0

0

33

17

$-8$

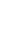

33

$-21$

17

19

10
Exits Through

Door

Num-

12

$-42$

24

33

Counting Num

Error (\%) -ber

$-8$

24

24

24

21

13

24

Exits

Counting

Error (\%)

4

8

42

12

$-33$

24

12

0

24

42

21

25

24

$-21$

48

25

24

17

48

17

36

$-4$

72

14

60

120

14

The accuracy of counting of naïve occupant passage through the lightly-used two-door of a conference room over multiple days of use is indicated by the numbers in Table 3 . In this application, counting errors were less than $10 \%$ for the total number of people who entered or 
exited through the door. However, when the net change in indoor occupancy was small (e.g., 15 occupants) the percentage error in counting of net change in occupancy could be high (46\%) although the absolute error were still modest (e.g., 7 occupants).

Table 3. Counting accuracy of PCS1 system with naïve occupants passing through a two-door entrance to a conference room.

\begin{tabular}{ccccccccc}
\multicolumn{2}{c}{ Entrance Through Door (s) } & \multicolumn{3}{c}{ Exit Through Door (s) } & \multicolumn{3}{c}{ Entrances Minus Exits } \\
Actual & Counted & Error & Actual & Counted & Error & Actual & Counted & Error \\
53 & 57 & $7.5 \%$ & 68 & 65 & $-4.4 \%$ & -15 & -8 & $7(-46 \%)$
\end{tabular}

The accuracy of counting of naive occupant passage through the four-door entrance of the office building is indicated by the numbers in Table 4. Because accuracy appeared to be reduced when the floor below the thermal sensors was illuminated and heated by sunlight, data were compiled for time periods with and without impingement of direct sunlight (determined visually) on the floor beneath the sensors. With no direct sunlight impinging on the floor, the errors in counting the number of people who entered or exited through the door were $13 \%$ or less. With direct sunlight on this section of floor, these errors were as high as $-26 \%$. As in the single door installation, when the net change in indoor occupancy was small the percentage error in counting of net change in occupancy was high (54\%).

Table 4. Counting accuracy of PCS1 system with naïve occupants passing through a four-door door entrance to an office building.

Sunlight* Entrance Through Doors

$\begin{array}{cccc} & \text { Actual } & \text { Counted } & \text { Error } \\ \text { No } & 149 & 168 & 13 \% \\ \text { Yes } & 110 & 81 & -26 \%\end{array}$

Exit Through Doors

Actual Counted Error

$180 \quad 194 \quad 8 \%$

$75 \quad 65-13 \%$

\begin{tabular}{ccc}
\multicolumn{3}{c}{ Entrances minus Exits } \\
Actual & Counted & Error \\
-31 & -26 & $5(-16 \%)$ \\
35 & 16 & $-19(-54 \%)$
\end{tabular}

* Direct sunlight impinging on floor beneath thermal sensors

\section{People Counting System Number 2.}

Table 5 provides a compilation of results of counting accuracy of PCS2 with controlled challenges at the single-door entrance to Conference Room 1. There were no counting errors when single persons walked through the door at a normal pace, even when carrying cups of hot coffee or warm laptop computers. The counter failed to detect people wearing a room temperature winter coat with hood over their head and their hands in the pockets, but detected people without error when the winter coat had just been removed from a freezer. When a single person walked through the door at a very fast pace, the counter failed to register a count $25 \%$ of the time. When two people walked side-by-side through the door simultaneously, the counter normally registered only a one-person change in count. When three or five persons walked through the door following each other as closely as comfortable, the system under counted by $40 \%$ on average. 
The results of controlled challenges of PCS2 installed at the entrance door of Room 3 are provided in Table 6. The results are similar to those discussed above, but with better counting accuracy when a single person walked very quickly through the door (no errors) and when three or five person walked through the door at a normal pace following each other as closely as comfortable.

Table 5. Results of controlled tests of PCS2 at a single interior door entrance to Conference Room 1, the numbers are averages of three repeated challenges.

\begin{tabular}{|c|c|c|c|c|c|c|c|}
\hline \multirow{2}{*}{ Test Conditions } & \multirow{2}{*}{$\begin{array}{l}\text { Room } \\
\text { No. }\end{array}$} & \multirow{2}{*}{$\begin{array}{l}\text { Cor- } \\
\text { rect } \\
\text { Count }\end{array}$} & \multicolumn{2}{|c|}{$\begin{array}{c}\text { Entrances } \\
\text { Through Door }\end{array}$} & \multicolumn{2}{|c|}{$\begin{array}{l}\text { Exits Through } \\
\text { Door }\end{array}$} & \multirow{2}{*}{$\begin{array}{c}\text { Entran } \\
\text {-ces or } \\
\text { Exits } \\
\text { Count- } \\
\text { ing } \\
\text { Error } \\
(\%)\end{array}$} \\
\hline & & & $\begin{array}{l}\text { Avg. } \\
\text { Count }\end{array}$ & $\begin{array}{l}\text { Count } \\
\text { - ing } \\
\text { Error } \\
(\%)\end{array}$ & $\begin{array}{l}\text { Avg. } \\
\text { Count }\end{array}$ & $\begin{array}{l}\text { Count } \\
\text {-ing } \\
\text { Error } \\
(\%)\end{array}$ & \\
\hline $\begin{array}{l}\text { single person walks through at a } \\
\text { normal pace }\end{array}$ & 1 & 1 & 1 & $0 \%$ & 1 & $0 \%$ & $0 \%$ \\
\hline $\begin{array}{l}\text { single person walks through at a } \\
\text { very fast pace }\end{array}$ & 1 & 1 & 0.67 & $-33 \%$ & 0.83 & $-17 \%$ & $-25 \%$ \\
\hline $\begin{array}{l}\text { single person walks through at a } \\
\text { normal pace with covered coffee } \\
\text { cup }\end{array}$ & 1 & 1 & 1 & $0 \%$ & 1 & $0 \%$ & $0 \%$ \\
\hline $\begin{array}{l}\text { single person walks through at a } \\
\text { normal pace with open coffee } \\
\text { cup }\end{array}$ & 1 & 1 & 1 & $0 \%$ & 1 & $0 \%$ & $0 \%$ \\
\hline $\begin{array}{l}\text { single person walks through at a } \\
\text { normal pace with a room } \\
\text { temperature winter coat with } \\
\text { hood on and hands in pockets }\end{array}$ & 1 & 1 & 0 & $-100 \%$ & 0 & $-100 \%$ & $-100 \%$ \\
\hline $\begin{array}{l}\text { single person walks through at a } \\
\text { normal pace, with a winter coat } \\
\text { from the freezer, with hood on } \\
\text { and hands in pockets }\end{array}$ & 1 & 1 & 0.67 & $-33 \%$ & 1 & $0 \%$ & $-17 \%$ \\
\hline $\begin{array}{l}\text { single person walks through at a } \\
\text { normal pace, with a warm laptop } \\
\text { computer held flat to the ground }\end{array}$ & 1 & 1 & 1 & $0 \%$ & 1 & $0 \%$ & $0 \%$ \\
\hline $\begin{array}{l}\text { two people walk through at a } \\
\text { normal pace, side by side, not } \\
\text { touching }\end{array}$ & 1 & 2 & 1 & $-50 \%$ & 1 & $-50 \%$ & $-50 \%$ \\
\hline $\begin{array}{l}\text { two people walk through at a } \\
\text { normal pace, side by side, arm } \\
\text { over shoulder }\end{array}$ & 1 & 2 & 1 & $-50 \%$ & 1 & $-50 \%$ & $-50 \%$ \\
\hline $\begin{array}{l}\text { two people walk through at a } \\
\text { normal pace, second person } \\
\text { follows first as close as } \\
\text { comfortable }\end{array}$ & 1 & 2 & 0.67 & $-67 \%$ & 1 & $-50 \%$ & $-58 \%$ \\
\hline $\begin{array}{l}\text { three people walk through at a } \\
\text { normal pace, one after another as } \\
\text { close as comfortable }\end{array}$ & 1 & 3 & 1.33 & $-56 \%$ & 2 & $-33 \%$ & $-44 \%$ \\
\hline $\begin{array}{l}\text { five people walk through at a } \\
\text { normal pace, one after another as } \\
\text { close as comfortable }\end{array}$ & 1 & 5 & 2.83 & $-43 \%$ & 3.5 & $-30 \%$ & $-37 \%$ \\
\hline
\end{tabular}


Table 6. Results of controlled tests of PCS2 at a single interior door entrance to room Room 3. the numbers are averages of three repeated challenges.

\begin{tabular}{|c|c|c|c|c|c|c|c|}
\hline \multirow{2}{*}{ Test Conditions } & \multirow{2}{*}{$\begin{array}{c}\text { Confer } \\
\text {-ence } \\
\text { Room } \\
\text { No.* }\end{array}$} & \multirow{2}{*}{$\begin{array}{l}\text { Cor- } \\
\text { rect } \\
\text { Count }\end{array}$} & \multicolumn{2}{|c|}{$\begin{array}{c}\text { Entrances } \\
\text { Through Door }\end{array}$} & \multicolumn{2}{|c|}{$\begin{array}{l}\text { Exits Through } \\
\text { Door }\end{array}$} & \multirow{2}{*}{$\begin{array}{c}\text { Entran } \\
\text {-ces or } \\
\text { Exits } \\
\text { Count- } \\
\text { ing } \\
\text { Error } \\
(\%)\end{array}$} \\
\hline & & & $\begin{array}{l}\text { Avg. } \\
\text { Count }\end{array}$ & $\begin{array}{l}\text { Count } \\
\text { - ing } \\
\text { Error } \\
(\%)\end{array}$ & $\begin{array}{l}\text { Avg. } \\
\text { Count }\end{array}$ & $\begin{array}{l}\text { Count } \\
\text {-ing } \\
\text { Error } \\
(\%)\end{array}$ & \\
\hline $\begin{array}{l}\text { single person walks through at a } \\
\text { normal pace }\end{array}$ & 3 & 1 & 1 & $0 \%$ & 1 & $0 \%$ & $0 \%$ \\
\hline single person walks through at a & 3 & 1 & 1 & $0 \%$ & 1 & $0 \%$ & $0 \%$ \\
\hline $\begin{array}{l}\text { single person walks through at a } \\
\text { normal pace with covered coffee } \\
\text { cup }\end{array}$ & 3 & 1 & 1 & $0 \%$ & 1 & $0 \%$ & $0 \%$ \\
\hline $\begin{array}{l}\text { single person walks through at a } \\
\text { normal pace with open coffee } \\
\text { cup }\end{array}$ & 3 & 1 & 1 & $0 \%$ & 1 & $0 \%$ & $0 \%$ \\
\hline $\begin{array}{l}\text { single person walks through at a } \\
\text { normal pace with a room } \\
\text { temperature winter coat with } \\
\text { hood on and hands in pockets } \\
\text { single person walks through at a }\end{array}$ & 3 & 1 & 0 & $-100 \%$ & 0.67 & $-33 \%$ & $-67 \%$ \\
\hline $\begin{array}{l}\text { normal pace, with a winter coat } \\
\text { from the freezer, with hood on } \\
\text { and hands in pockets }\end{array}$ & 3 & 1 & 0.67 & $-33 \%$ & 1 & $0 \%$ & $-16 \%$ \\
\hline $\begin{array}{l}\text { single person walks through at a } \\
\text { normal pace, with a warm laptop } \\
\text { computer held flat to the ground }\end{array}$ & 3 & 1 & 1 & $0 \%$ & 1 & $0 \%$ & $0 \%$ \\
\hline $\begin{array}{l}\text { two people walk through at a } \\
\text { normal pace, side by side, not } \\
\text { touching }\end{array}$ & 3 & 2 & 1 & $-50 \%$ & 0.67 & $-67 \%$ & $-58 \%$ \\
\hline $\begin{array}{l}\text { two people walk through at a } \\
\text { normal pace, side by side, arm } \\
\text { over shoulder }\end{array}$ & 3 & 2 & 0.83 & $-58 \%$ & 0.83 & $-58 \%$ & $-58 \%$ \\
\hline $\begin{array}{l}\text { two people walk through at a } \\
\text { normal pace, second person } \\
\text { follows first as close as } \\
\text { comfortable }\end{array}$ & 3 & 2 & 1.83 & $-8 \%$ & 2 & $0 \%$ & $0 \%$ \\
\hline $\begin{array}{l}\text { three people walk through at a } \\
\text { normal pace, one after another as } \\
\text { close as comfortable }\end{array}$ & 3 & 3 & 3 & $0 \%$ & 3 & $0 \%$ & $0 \%$ \\
\hline $\begin{array}{l}\text { five people walk through at a } \\
\text { normal pace, one after another as }\end{array}$ & 3 & 5 & 5 & $0 \%$ & 4.67 & $-6 \%$ & $-3 \%$ \\
\hline
\end{tabular}
close as comfortable

*Room was size of a small meeting room but used for offices

The accuracy of counting of naïve occupant passage through the single door of Conference Room 1 is indicated by the numbers in Table 7. Data are provided for 1.0 to 1.5 hour periods on four dates. Excluding data from a period when people were standing in the doorway, the errors in total counts of people entering or exiting the conference room ranged from $0 \%$ to $-14 \%$ and averaged $-5 \%$. These errors in total counts reflect some over counting counteracted by some undercounting, thus, the percentage of counting events in which an error occurred was higher ( $0 \%$ to $20 \%$ with an average of $8 \%$ ). On one date there was a period in which people stood for an extended period in the doorway because the meeting room was full. Total count errors were 
$+29 \%$ for people entering and $-50 \%$ for people exiting during this period but the number of imperfect accounts was as high as $171 \%$ of the correct count.

Table 7. Counting accuracy of PCS2 with naïve occupants passing through single-door entrances to Conference Rooms 1 and 2.

\begin{tabular}{|c|c|c|c|c|c|c|c|}
\hline Room & 1 & 1 & 1 & 1 & 1 & 1 & 2 \\
\hline Time Period & $9 / 9$ & 9/11 & $10 / 6$ & $\begin{array}{c}\text { 10/7 } \\
\text { (no } \\
\text { standing } \\
\text { in door) }\end{array}$ & $\begin{array}{c}10 / 7 \\
\text { (with } \\
\text { standing } \\
\text { in door) }\end{array}$ & $\begin{array}{c}/ 9-10 / 7 \\
\text { All } \\
\text { Periods } \\
\text { (no } \\
\text { standing } \\
\text { in door) }\end{array}$ & $12 / 18$ \\
\hline \multicolumn{8}{|c|}{ Entrances Into Room } \\
\hline Correct count & 20 & 45 & 27 & 62 & 7 & 154 & 31 \\
\hline Counted & 17.5 & 44.5 & 27 & 60 & 9 & 149 & 30 \\
\hline Error \% & $-13 \%$ & $-1 \%$ & $0 \%$ & $-3 \%$ & $29 \%$ & $-3 \%$ & $-3 \%$ \\
\hline Missed full counts & 1 & 1 & 0 & 2 & 2 & 4 & 0 \\
\hline False full counts & 0 & 0 & 0 & 0 & 4 & 0 & 0 \\
\hline Undercounts by 0.5 & 3 & 0 & 0 & 0 & 3 & 3 & 2 \\
\hline Over counts by 0.5 & 0 & 1 & 0 & 0 & 3 & 1 & 0 \\
\hline Imperfect counts* \% & $20 \%$ & $4 \%$ & $0 \%$ & $3 \%$ & $171 \%$ & $5 \%$ & $6 \%$ \\
\hline \multicolumn{8}{|c|}{ Exits from Room } \\
\hline Correct count & 16 & 33 & 29 & 46 & 3 & 124 & 37 \\
\hline Counted & 16 & 31.5 & 29 & 39.5 & 1.5 & 116 & 38 \\
\hline Error \% & $0 \%$ & $-5 \%$ & $0 \%$ & $-14 \%$ & $-50 \%$ & $-6 \%$ & $3 \%$ \\
\hline Missed full counts & 0 & 2 & 0 & 6 & 1 & 8 & 0 \\
\hline False full counts & 0 & 1 & 0 & 0 & 0 & 1 & 1 \\
\hline Undercounts by 0.5 & 1 & 1 & 0 & 1 & 1 & 3 & 2 \\
\hline Over counts by 0.5 & 1 & 0 & 0 & 0 & 0 & 1 & 1 \\
\hline Imperfect counts* \% & $12 \%$ & $12 \%$ & $0 \%$ & $15 \%$ & $67 \%$ & $10 \%$ & $14 \%$ \\
\hline \multicolumn{8}{|c|}{ Entrances or Exits } \\
\hline Correct count & 36 & 78 & 56 & 108 & 10 & 278 & 68 \\
\hline Counted & 33.5 & 76 & 56 & 99.5 & 10.5 & 265 & 68 \\
\hline Error \% & $-7 \%$ & $-3 \%$ & $0 \%$ & $-8 \%$ & $5 \%$ & $-5 \%$ & $0 \%$ \\
\hline Imperfect counts* \% & $17 \%$ & $8 \%$ & $0 \%$ & $4 \%$ & $93 \%$ & $15 \%$ & $10 \%$ \\
\hline
\end{tabular}

* Percentage of total events in which a counting error was noted. An event is the passage on one or more persons simultaneously or in close succession through the door, followed by a period with no persons passing through the door.

The accuracy of counting of naïve occupant passage through the single door of Conference Room 2 is indicated by the numbers in right most column of Table 7 . On this date, no occupants stood in the door, counting errors were $-3 \%$ and $3 \%$ for people entering and exiting the room, respectively, and imperfect counts were $10 \%$ of total counts. 


\section{DISCUSSION}

\section{People Counting System Number 1}

This pilot study of the PCS1 indicates that counting accuracy in some situations can be relatively high with errors on the order of $10 \%$. However, relatively high counting errors occurred in the following demanding situations: 1) people carrying cups of hot coffee; 2) people following very closely behind each other when they pass through the door; 3) people in physical contact when passing through a doorway; 4) people wearing a room temperature winter coat with hood over their head, and 5) direct sunlight heating the floor located beneath the thermal sensors. The third and fourth of these situations are likely to occur infrequently, at least in most California climates. One could avoid using the PCS1 at locations where direct sun may heat the floor beneath the thermal sensors and the manufacturer indicated that changes in the type of floor matt or moving the detection lines further indoors from the door might have reduced these errors.

In planning the testing of PCS1 for office building applications, the required minimum sensor height of $3.05 \mathrm{~m} \mathrm{(10} \mathrm{ft)} \mathrm{made} \mathrm{the} \mathrm{system} \mathrm{impractical} \mathrm{for} \mathrm{many} \mathrm{building} \mathrm{and} \mathrm{conference} \mathrm{room}$ entrances. The manufacturer is developing a system that can be installed at a lower height, but this system was not evaluated.

\section{People Counting System Number 2}

In the controlled challenges of PCS2, counting accuracy was high when single individuals passed through the doorway at a normal pace. Carrying warm objects such as hot coffee or a warm laptop computer did not lead to counting errors. The counter often did not detect a person wearing a room temperature winter coat with hood over their head, but such events are likely very rare for interior doorways. In the first set of controlled tests, there was a substantial undercounting in some highly challenging events such as persons walking through the door at a very fast pace, two people passing through the door simultaneously, and people passing through a door sequentially as closely as comfortable. The accuracy in some of these situations was higher in the second set of controlled challenges. These controlled tests were performed with volunteers as subjects who differed between the two sets of controlled experiments. The results may have differed because the subjects in the first and second set of controlled tests walked at different speeds or with different distances from others. Additionally, as discussed previously, the start threshold was modified between the two sets of controlled tests.

The accuracy of counting naïve occupants as they entered or exited Conference Room 1 and Room 2 was generally high, suggesting that the highly challenging events noted above are rare, but more data are necessary before drawing this conclusion. However, the counter was found to be unsuitable for situations in which people stood in the doorway. In the present studies, this occurred when all seats of the conference room were utilized and a seminar presentation was underway. This situation was not encountered is tests of PCS1. 
PCS2 was easy to install and, based on the installation instructions, is usable in most interior doorways. The system does require that the building have a BACnet communication system, which limits its applicability in the current building stock.

\section{General Observations}

This pilot testing of people counting systems has several limitations that prevent any firm conclusions about the suitability of these systems for providing a control signal for demand controlled ventilation. The tests involved only a few sensors, new sensors, a few installation sites, and limited periods of testing. Also, with additional experience the positions of the "lines" that subjects must cross to trigger a count might be adjusted to improve accuracy of PCS1 and the aforementioned settings might be changed to improve the accuracy of PCS2 for specific applications. Based on the pilot findings, it is clear that both counting system have limitations and would need to be used only at appropriate sites and where the demanding situations that led to counting errors were rare. In evaluation of the utility of these people counting systems for demand controlled ventilation one must keep in mind the advantages and disadvantages of people counting that were discussed in the introduction to this report and that that the widely used alternative sensors for demand controlled ventilation (low cost carbon dioxide sensors) often have large errors.

No costs were available for the prototype PCS2. The cost of people-counting-based demand controlled ventilation with PCS1, relative to the cost of $\mathrm{CO}_{2}$-based demand controlled ventilation, will depend on the application. The price of the counting hardware for a single door entrance was $\$ 1450$ while unit costs for single-point $\mathrm{CO}_{2}$ sensors are typically $\$ 300$ to $\$ 500$. The California Title 24 code requires a minimum of one sensor per $930 \mathrm{~m}^{2}\left(10,000 \mathrm{ft}^{2}\right)$ of floor area where demand controlled ventilation is employed, thus, $\mathrm{CO}_{2}$ sensor costs will be substantially lower for most small or moderate-size rooms if the minimum number of $\mathrm{CO}_{2}$ sensors are installed. However, for full building applications the costs of $\mathrm{CO}_{2}$ sensors at one or more sensor per $930 \mathrm{~m}^{2}\left(10,000 \mathrm{ft}^{2}\right)$ of floor area could exceed the cost of people counting hardware. Installation costs per sensor should be similar for both types of sensors. People-counting-based demand controlled ventilation systems require a measurement system for the outdoor air intake rate which can be costly and inaccurate. $\mathrm{CO}_{2}$-based demand controlled ventilation is normally utilized without a system for measuring outdoor air intake flow rates, although, because such measurement systems are absent, minimum ventilation rates per unit floor area may often be poorly controlled. The relative costs will also depend on sensor lifetimes, which are currently unknown for both people counters and $\mathrm{CO}_{2}$ sensors. Finally, the effectiveness of the systems in controlling minimum ventilation rates will have a large impact on their cost effectiveness. Field studies have found that many of the $\mathrm{CO}_{2}$ sensors used for demand controlled ventilation have large errors (Fisk et al. 2009). Thus, $\mathrm{CO}_{2}$-based demand controlled ventilation is frequently not providing the desired level of control of ventilation rates. This scale and scope of this pilot study was too small for firm conclusions about the energy savings potential of demand controlled ventilation based on people counting; however, the findings from this pilot study are sufficiently promising to indicate that further investigations of people counting are warranted. 


\section{CONCLUSIONS}

The two people counting systems had high counting accuracy accuracies, with errors typically less than $10 \%$, for typical counting events. However, counting errors were high in some highly challenging situations. Counting errors can be very high if people stand in the zone where the counters detect moving people. Both counting system have limitations and would need to be used only at appropriate sites and where the demanding situations that led to counting errors were rare.

The requirement for a high sensor height substantially limits the applicability of PCS1. The manufacturer is developing a system that can be installed at a lower height.

This scale and scope of this pilot study was too small for firm conclusions about the energy savings potential of demand controlled ventilation based on people counting; however, the findings from this pilot study are sufficiently promising to indicate that further investigations of people counting are warranted.

\section{ACKNOWLEDGMENTS}

The authors thank Dennis Dibartolomeo for assistance with electronics and software, Mike Spears for collecting some of the data, David Faulkner for assistance with purchasing, David Faulkner and Mike Apte for reviews of a draft of this document, and Brad Meister at the California Energy Commission for project management.

\section{REFERENCES}

Brandemuehl, M. J. and J. E. Braun (1999). "The impact of demannd controlled and economizer ventilation strategies on energy use in buildings." ASHRAE Transactions 105(2).

Emmerich, S. J. and A. K. Persily (2001). State of the art review of $\mathrm{CO}_{2}$ demand controlled ventilation technology and application. ISTIR 6729. Gaithersburgh, MD, National Institute of Standards and Technology.

Fisk, W. J. and A. T. de Almeida (1998). "Sensor based demand controlled ventilation: a review." Energy and Buildings 29(1): 35-44.

Fisk, W. J., D. Faulkner and D. P. Sullivan (2006). "Measuring outdoor airflow into HVAC systems." ASHRAE Journal 48(8): 50-57.

Fisk, W. J., D. Faulkner, D. P. Sullivan and E. Eliseeva (2009). $\mathrm{CO}_{2}$ monitoring for demand controlled ventilation in commercial buildings. Berkeley, CA, Lawrence Berkeley National Laboratory. 